\title{
How sustainable are companies?
}

\author{
Die Bewertung von Firmen unter Nachhaltigkeitskriterien ist immer noch \\ schwierig. Es ist in erster Linie der Mangel an verlässlichen und vergleichbaren \\ Informationen über Firmen, die eine umfassende Beurteilung verhindert. Das \\ Projekt Sustainabiliy Performance Benchmarking hat umfassend Schlüsseldaten \\ für verschiedene Sektoren gesammelt und ausgewertet.
}

T

Von Julia Hertin here are many claims about the social and environmental performance of businesses. Companies often assert that they are sustainability leaders or at least working hard to improve. NGOs tend to criticise the standards and practices of firms, for example in relation to local and global pollution or working conditions. More recently, ethical investment analysts have begun to provide systematic assessments of the sustainability performance of large corporations, but it is not rare that a business highly evaluated by one ratings agency is given a low score by another. It is difficult to validate these claims and the need for more transparency becomes more urgent as stakeholder-driven forms of governance are gaining in importance. In an argument which is empirical and functional as well as normative, many now think that a wide range of stakeholders do, can, and should put pressure on companies to improve their social and environmental performance. As a result, a far larger range of stakeholders need to know more about how individual companies behave in relation to different ethical issues.

\section{The unknown quantity}

Analysing the common sources of information, however, suggests that real transparency is still a long way away. Most stakeholders have limited and unsystematic knowledge about the ethical record of companies and products. Especially less professionalised actors such as local communities and private consumers tend to have little access to relevant information, but also policy-makers and ethical investors often need to make decisions in the absence of appropriate knowledge. One of the indications for the current information gap is the large number of surveys carried out by investment analysts, NGOs, business customers and others which has lead to the frequently cited phenomenon of 'questionnaire fatigue'. In the UK, more than a hundred organisations have recently joined the Corporate Responsibility coalition to press government and the private sector for more transparency on the social and environmental impacts of business operations.

There are number of reasons for the continuing lack of reliable and systematic information sources on corporate sustainability:

- The availability and quality of data tends to be poor as most countries do not require companies to disclose sustainability information. Although a number of large companies now publish environmental and sustainability reports, these still represent a small minority of overall economic activity. The reports do not always provide any quantitative information.

- Because sustainability issues are complex, value-laden and often hard to quantify, it is difficult to define measures of 'good environmental and social performance'. Weighting and aggregating individual indicators to a broader score is inherently subjective and a widely accepted methodology does not yet exist.

- Comparing the sustainability profiles of firms can be problematic because each engages in slightly different activities. Environmental performance differences are often the result of structu-

\section{Einen Überblick über alle bisher erschienenen Hefte des Informationsdienstes Ökologisches Wirtschaften} finden Sie auf unseren Internetseiten unter der Adresse: www.oekom.de Wir freuen uns auf Ihren Besuch! ral factor and of the specific market and technological niche in which companies operate. For example, companies that buy in certain raw materials may appear to be 'cleaner' than others who manufacture them in-house.

\section{The PERFORM project}

Sustainability Performance Benchmarking (PERFORM) is a research project designed to make progress towards addressing this knowledge gap (1). Led by researchers at SPRU at the University of Sussex, PERFORM collects, publishes and analyses data about the sustainability performance of companies in large industrial sectors. It currently covers 14 sectors: aggregates, aluminium, cement, ceramics, electricity, glass, motor vehicles, paper, plaster, plastics, printing, steel, timber, and water. The research is funded by the UK Department of Trade and Industry, the British Research Council EPSRC, Biffaward, and the Engineering Employers' Federation. It has been endorsed by nine UK trade associations.

The approach to measuring sustainability balances rigour with pragmatism. It is based on the acknowledgment that systems which comprehensively capture data for all material and energy flows do not exist and that there is no definitive way of measuring the sustainability performance of a company. The project draws on current reporting conventions and standards. After evaluating existing indicator lists and consulting with business, regulators and sector experts, a list of 26 generic indicators and a small number of sector-specific metrics was agreed on. They cover:

- environmental performance: energy use, water use, waste and air emissions, product responsibility, supply chain;

- social performance: employment, health \& safety, training, and equal opportunities; and

- economic performance: turnover, profit, return on capital and productivity.

\section{- The difficult search for data}

Most companies approached during the project were very reluctant to provide the project with sustainability data unless it was already in the public domain. The main reasons given were 'general lack of interest' (particularly prevalent in SMEs), 'no clear benefits for the company' and 'lack of resources', as well as in some cases 'non-availability of data' and 'participation in other sustainability initiatives'. During the process of engagement, the following interesting insights emerged: 
Environmental managers were often interested in comparing the performance of their company, for example to help 'make the case' for sustainability in boardrooms. Senior management, however, tended to be cautious about confidentiality and sceptical about benefits of disclosure.

Some leading companies were keen to contribute to more transparency as it would enable them to demonstrate good performance, but the majority of firms were nervous about quantitative reporting. Even companies that publish some quantitative information in reports were unwilling to give up control over disclosure by providing data in a comprehensive format.

Most of the data for common sustainability indicators is available 'in principle', but the effort to gather it can be substantial. Only a few large companies have mature integrated reporting systems. The lack of standardisation remains a barrier to benchmarking.

The low response rate from companies raises questions about the perceived priority of sustainability in companies and the willingness to improve transparency. It also meant that data collection had to rely on previously published sources such as company reports and public pollution inventories. Despite this limitation, a large database was built up: A total of 10700 data points were collected covering 133 firms, 46 business units and 300 sites and three years (2000 to 2002). The distribution was uneven across sectors with the best data in paper and electricity sector and virtually no quantitative information for aggregates, plastics and timber companies. Data availability also varied for different indicators. While social performance reporting is still underdeveloped, disclosure of information on environmental performance is fairly common in large firms, particularly on key air emissions, waste, energy and water use. Little data is published on operational performance (e.g. compliance and accidents), less common pollutants and supply chain issues.

\section{- Complex answers to difficult questions}

Disaggregated results for all individual companies and production sites have been compiled and published on the project website. They can be accessed by the companies themselves as well as interested stakeholders and researchers. The results are interesting in a number of respects: There is a huge variability in performance across different producers. On many indicators, the best companies or sites manufacture the same amount of output with 100 or 1000 times less resources, waste or emissions than the poorest performers. At the same time, consistency in performance was usually limited to related indicators. For example, a company with high carbon dioxide emissions is likely to also have high nitrogen oxide emissions, but may produce little hazardous waste.

Except for a minority of indicators, performance does not follow a normal distribution curve. Instead, the pattern of distribution varies across sectors and indicators, with some severely skewed (a long tail of good or poor performers) while others show a rather uniform distribution. Where the trend was measured over several years, we found that there is only a very slight positive tendency: 49 per cent of all indicator trends were improving, 45 per cent worsening and six per cent remaining unchanged over the period analysed. While the majority of companies reported more use of renewable electricity, fewer complaints and higher profitability, there were on average more environmental prosecutions, less recycling, and less staff training.

In a second step, statistical analysis was carried to establish whether there is a correlation between sustainability performance and a number of firm characteristics such as size, profitability, type of product or technology, and type of environmental management system. However, the characteristics of the data set - non-normal distribution, large share of missing data and uneven coverage - limit the explanatory power of the analysis. To generate valid results, it was necessary to examine each sector individually and to focus on indicators with the best availability of data. The statistical analysis led to the following findings:

- In most sectors, basic technology and products explain a considerable amount of the variability in environmental performance. Although this is not a surprising result, it is a valuable reminder of the structural rigidities of environmental performance which are not always sufficiently acknowledged.

- Out of seven sectors analysed, significant positive correlations between the type of environmental management system (EMS) and performance could only be found in the aluminium, electricity, motor, paper sector and only for a minority of indicators. In the steel and cement sectors, producers with a higher-level EMS performed worse on a some indicators.
- In contrast to our expectations, we found that small firms often performed better than large ones, except in motor manufacturing. At the site level, results were mixed: Larger sites tended to do better in motor manufacturing, but worse in electricity. More often than not, however, there was no correlation between size and performance.

- There were only very few significant correlations between profitability and environmental performance, with no clear pattern emerging across sectors or indicators.

More detailed analysis of these results - which may appear contradictory and even arbitrary - in fact highlights that sustainability performance is a complex phenomenon which does not lend itself to simple answers. For example, it seems plausible that small electricity plants (many of which will be small scale renewables and combined heat and power) perform better than large power stations which often fuelled with coal, while car production plants with large output are more likely to adopt very modern and eco-efficient technologies.

While initiatives such as PERFORM make a valuable contribution towards more transparency, there remains a shortage of reliable sustainability information in the public domain. This has at least three negative consequences: First, the high cost of gathering information leads analysts to protect their data in order to recover their investment through commercial products, inducing a 'vicious circle of confidentiality'. Second, sustainability evaluations based on poor data will undermine the confidence of stakeholders and companies in this field. Third, there is a risk that companies that publish this information are penalised because they are more thoroughly scrutinised than their competitors. It appears unlikely that this situation will fundamentally change stricter reporting requirements are introduced.

\section{Reference}

(1) For more details see www.sustainabilityperformance.org

\section{Die Autorin}

Julia Hertin ist Research Fellow bei SPRU - Sciene and Technology Policy Research an der University of Sussex.

Kontakt: SPRU, Freeman Centre, University of Sussex, Brighton, BN1 9QE, GroBbritannien. E-Mail: j.hertin@sussex.ac.uk 
(c) 20I0 Authors; licensee IÖW and oekom verlag. This is an article distributed under the terms of the Creative Commons Attribution Non-Commercial No Derivates License (http://creativecommons.org/licenses/by-nc-nd/3.o/), which permits unrestricted use, distribution, and reproduction in any medium, provided the original work is properly cited. 